\title{
Rethinking Responsibility and Care for a Postcolonial World
}

\begin{abstract}
:
Both responsibility and care have much to offer in thinking through the relationalities that make up a postcolonial world. Although contemporary political systems often posit responsibility and care within the context of individuated and autonomous selves, geographers have done much to relocate responsibility and care within narratives of interdependency - spatially and temporally. They have argued that both terms offer a route for thinking about ethical geographical relations between myriad places. In this article we take this project further, by looking at how the nature and shape of these relationships might be construed in a postcolonial world. We suggest that, through a more critical engagement with postcolonial thinking, any exploration of existing practices of responsibility and care will not only reveal the enormous potential of imagining these geographies as forms of existing and evolving relationalities, but will also lead us to interrogate the deployments of these terms in the context of past and present inequalities. We show that routing care and responsibility through postcolonial geographies moves us towards a more pragmatic responsiveness, one that involves a 'care-full' recognition of postcolonial interaction.
\end{abstract}

Keywords: care, responsibility, postcolonialism 


\section{Introduction}

In recent years geographers have shown considerable interest in notions of responsibility and care and how they can help to move us towards a more ethical geography (Lawson, 2007; Massey, 2004; Popke, 2007; Sparke, 2007a). Through their ability to emphasise relationality and interdependence, these concepts of care and responsibility challenge wider moves within public policy towards an autonomous, responsibilised self (Clarke, 2005). Thus a range of writers have contested such individualised versions of care and responsibility by highlighting the inherently relational interdependence that marks the globalising world (Bosco, 2007; Cupples et al, 2007; Jazeel, 2007). In so doing, notions of responsibility and care are mapped onto a framework for ethical living.

In this introduction to the special issue and overview of the literature, we outline some of the ways in which geographers have written about these interdependencies of responsibility and care and the spatial and place based relations within which they are embedded ${ }^{1}$. We then move towards thinking through how the accepted temporal and spatial frames in which responsibility and care are usually imagined in the geographical literature may be extended by routing them through the imperatives of a postcolonial world. In this venture we contribute to other attempts to nuance understandings of responsibility and care within geography. For instance, a recent special issue on geographies of generosity (Geoforum 2007, 38) takes as its starting point a critique of the politico-moral underpinnings of responsibility and care as calls to political action. Barnett and Land (2007, p.1073) argue convincingly that geographies of care and responsibility over distance are linked by a similar 'wrongheadedness' about motivations to political action. They suggest that 
formulations of geographies of care often start from the assumption that relatively privileged people do not care about 'distant strangers' and should be made to care through reasoned arguments, whilst geographies of responsibility often assume that revealing causal links between the actions of relatively privileged people and the suffering experienced by many others globally will lead to a greater sense of political responsibility. They argue the partiality inherent in caring and responsible relations should be seen not as a flaw or shortcoming but as the condition of ethical relations. Moreover, they emphasise the nature of power relations involved in such interdependent relations, taking us some way towards a postcolonial reading of care and responsibility. Towards this, Barnett and Land (2007, p.1073) suggest 'the adoption of a less exhortatory, more exploratory' programme of research around the everyday practices of caring and responsiveness.

This special issue on 'Postcoloniality, responsibility and care' aims to focus on these everyday practices in order to take questions of responsibility and care in yet another direction. And although we agree with Barnett and Land (2007) that responsibility and care are useful notions for invigorating and shaping political practice, we suggest that a more critical engagement with postcolonial thinking will reveal not only the intimacies and generosities within existing practices of care and responsibility, but also expose their political contestations and the pain and the absences that underpin global relationships touched by histories of (post)colonisation, exploitation and inequality. Hence our aim in this special issue is not to jettison geographies of responsibility and care, but to urge geographers to explore both the enormous potential of imagining these geographies as forms of existing and evolving relationality, and also to continually interrogate the deployments of these terms in the 
context of the complex spatial matrices and (dis)connectivities that are central to a postcolonial world. This deliberate re-placing of theoretical geographies of responsibility and care within postcolonial relationalities continues the postcolonial method elaborated in a previous publication (see Raghuram and Madge, 2006, p. 27980).

The potentialities and the limits to responsibility and care as viewed through a postcolonial frame will be explored in this article through five moves. Following this first introductory section, in the second section, we provide a schematic overview of some of the geographical literature on care, while the third section offers a brief outline of some of the literature on responsibility within geography. This moves us to summarise in our fourth section three ways in which a postcolonial reading might present an insistent challenge to current geographical literature on responsibility and care: through complicating ideas of proximate and distant relations; by rethinking the frame of temporality; and in questioning the centre from which care and responsibility can be talked about. In doing so, we argue that geographers must interrogate the multiple historical materiality of spatial relationships, expressing these as geographically-routed power dynamics, and use this understanding to both explore

and generate forms of engaged pragmatic responsiveness. The fifth section offers a brief conclusion as well as an introduction to the papers and themes explored in this special issue.

\section{Geographies of care}

In the past few years there has been growing academic interest in geographies of care (see for instance Social and Cultural Geography 2003, 2004; Environment and 
Planning A 2003). Increasing concern over how to think ethically and act responsibly in an interconnected world has led to much discussion of how such an ethical responsibility can be enacted both towards those who are in close proximity as well as towards those who are spatially distant (Silk, 2004). The notion of care offers an affective register to this discussion and also locates this responsibility in embodied enactments of care. It thus offers academics a mode of invocation for responsibility that draws on proximate relations, but makes these phenomenological experiences of care available for projecting out to distant relations and responsibilities. In picking up interest in questions of care, the geographical literature focuses on three key bodies of work: ethical spatial relations; how care is stretched across space in different ways; and the spatial (re)arrangements involved in care-giving and care-receiving. These three themes are outlined below.

\section{Ethical spatial relations}

Although there is a large literature on care in a range of disciplines, focusing on different forms that care-giving and care-receiving may take based on variations in the market (unpaid, unpaid subsistence, informal market work, paid), characteristics of the labour process (direct care, indirect care) and kinds of beneficiaries (child, sick, disabled, able-bodied adult, self) (Folbre, 2006), it is the inherent spatiality of care and the ongoing redistribution of care across places and spaces that have been the focus of the geographical literature on care. Thus, in a wide-ranging overview, Popke (2006) outlines some ways in which geographical literature has found the concept of care useful for evoking ethical spatial relations in a number of sites, through different practices and at different levels of abstraction. Concerns over people and place in care-giving practices are central to this strand of work (Milligan, 2003). There is a 
large emphasis on caring for the elderly (Milligan, 2003), ill, disabled (Hughes et al., 2005), homeless (Johnsen et al., 2005) and children, and on care-giving in a number of sites such as the home, community drop-in centres (Conradson, 2003), hospices (Brown, 2003) and hospitals (Fannin, 2003). This view of care draws on, and contributes to, insights in health geographies (Parr, 2003) as detailed ethnographic work explores how such care is mediated in particular socio-economic settings. However, place does not simply provide a background in which caring is enacted. Rather, as Bondi (2003) suggests, care is a quality of spaces that are produced relationally. Thus in her analysis of counselling she shows that training counsellors to care for their clients is ultimately also about creating spaces of care.

Many of these studies on ethical spatial relations focus on individuals who require care because of disability, ill-health, or due to their age and their relationships with carers who are largely seen as responsible, autonomous subjects. In these accounts the care needs of the carer and the cared-for are held distinctively apart as care flows out from the care-giver to the care-receiver, each constituted as distinct subjects. Moral agency usually lies with the carer although it is always produced in relation to those who are cared for. The ethics of relationality lie in making this carework as effective and responsible as possible. We are urged to be responsible enough to care, and to care well ${ }^{2}$.

How care is stretched across space in different ways

Geographical research has also explored the ways in which this care is stretched across space in different ways. Thus, authors contributing to a special issue in Social and Cultural Geography (2004) on caring at a distance highlight the ways in which 
care flows out from the global North to the South. They focus on how care is enacted within the discursive frameworks of much development literature. Although some authors (see for example, Silk, 2004) suggest that this is only one side of a complex equation of care, i.e. that care may be extended both across the South and from South to North (Kofman and Raghuram, 2007), the underlying theme remains that the virtue of care can be expanded out from interpersonal, proximate relations towards those whom one may not personally know. This relation of care underpins an ethic of responsibility in an interdependent world. Silk (2004) suggests that one way of thinking about such care is through embodied acts, the myriad daily practices, through which care is performed. Ethical consumption - the purchase of ethical goods for consumption by the self or as gifts to proximate others - may be seen as one way of participating in these 'caringscapes' (McKie et al., 2002; Clarke et al., 2007). Here care for distant others is being enacted through care of the intimate other or care of the self.

\section{The spatial (re)arrangements involved in care-giving and care-receiving}

The spatial (re)arrangements involved in care-giving and care-receiving too have received considerable attention from geographers. The relocation of care from the private to the public sphere (see Sevenhuijsen, 2003) and back again have called forth different forms of regulation and emotive and political responses. A range of social changes, especially changing family forms and nature of provisioning within welfare states (Staeheli and Brown, 2003), had meant that in the recent past more and more carework was being performed in public spaces such as old-age homes, nurseries and hospices rather than within the household. However, recent shifts in the welfare state have led to a reprivatisation of significant parts of this provision in many countries. In 
the welfare states of Northern and Western Europe public welfare provision has shrunk so that families increasingly have to resort to private solutions to what had briefly been scripted as a public issue (Ungerson, 1999; Ungerson and Yeandle, 2007). In the U.K., the mode of public provisioning has also altered as those who need care are now required to select and arrange for their own care for which the government then repays them through the direct payment scheme. This effectively locates those who require care as responsible, active citizens but it also alters the nature of the relationship between the carer and the cared-for by making the latter the entrepreneurial employers of the former. It takes the individualisation and commodification of care inside the home in new directions. Thus, just as nannies at home are replacing formalised publicly provided childcare, so too are private individuals replacing state-employed care assistants (see for instance Ilcan et al., 2007; McDowell, 2004; Staeheli and Brown, 2003). Having escaped the domestic terrain, the terms and quality of care have become the subject of calculative processes and regulations that are characteristic of the public sphere and in the most recent round of redomestication of care, these processes have also moved back 'home'. The caricature of the 'nanny state' expresses some of the discontent around the shifts in the adjudicative boundary between the private and the public that are being played out in these complex relocations of care.

These rearrangements also increasingly stretch out across the globe. The growth of the two wage family, underlain by a shift in welfare policies from the family wage to adult worker model, has catapulted more and more women into the workplace and has led to a care deficit in some households which is then filled in the care chain through 'a series of personal links between people across the globe based on the paid or 
unpaid work of caring' (Hochschild, 2000, p.131). Drawing on Parreñas's work (2000, 2001) on migration of nannies from the Philippines to the U.S., Arlie Hochschild (2000) argues that such migration simply transfers the care deficit from households in the U.S. to households in the Philippines. The next link in the chain is generated when this mobility then sparks further mobility, as women move from poorer parts of the Philippines to look after the families of these international migrants. Yeates (2004) usefully compares these chains to the links that make up the commodity chain. In conjunction with the wider feminist literature, much of this debate also focuses on how we look after the carers in our society more effectively and suggests that one way to do this is to revalue care (Kofman and Raghuram, 2006; Razavi, 2007).

However, in thinking about caring relations, whether near or far, much of the literature in geography reviewed above is embedded in a call to care where care is posited as normatively 'good' and based on an unproblematic assumption of 'need' which invokes 'an asymmetrical orientation towards the other' (Cooper, 2007, p.244). Thus according to Beasley and Bacchi (2007, p. 283, 285), the hierarchical nature of many caring relationships goes almost unnoticed and much of the literature presupposes relations of dependence and vulnerability. Moreover, the analytical focus of much of the literature on caring activities, concepts and models has been limited to states in the global North (Esping-Anderson, 1999). There is also increasing recognition of limitations of care as a concept for the global South and of the need to understand both overarching global processes and the heterogeneous local arrangements involved in procuring care (Kofman and Raghuram, 2007) while attempting to theorise care arrangements in the South. However, despite these 
limitations, the ability to bring together emotive, moral and political registers has meant that care does offer a route into thinking ethically about relationships between self and others - both proximate and distant. It therefore claims to offer much to geographical thinking. So too has the responsibility literature claimed to offer much to geographical thinking, as outlined below.

\section{Geographies of Responsibility}

Responsibility is another term that has gained wide currency within geography with the special issue of Geografisker Annaler B (2004) entitled Geographies of Responsibility being cited as a significant intervention in the field. The articles in this collection offer a sustained engagement with the political implications of conceiving global responsibility as embedded within the 'power-geometries' of relational space. This line of thinking has also been elaborated and nuanced through the work of a range of other writers in geography (Barnett 2005; Barnett and Land, 2007; Bosco, 2007; Brock, 2005; Jazeel, 2007; Noxolo et al., 2008; Popke, 2003; 2007; Sparke, 2007b). Some of these discussions of responsibility have centred around addressing inequality, in particularly the responsibilities of richer countries and people towards those who are less wealthy or distanciated, often evoked through the figure of the 'distant stranger' (Patai, 1991; Corbridge, 1993, 1998; Smith, 2002). Other studies have revealed the distinctive temporal dimensions of these relationships, both the importance of the past in shaping the present (Andreasson, 2005; Biccum, 2005; Cupples et al, 2007; Kapoor, 2004; Sharpe and Briggs, 2006) and also the need to think about responsibility to those who will come in the future, especially in relation to the environment (Armstrong, 2006; Baldwin, 2004; Hillman, 2004; Hobson, 2006; Richardson, 2004) ${ }^{3}$. In this wide ranging literature on geographies of responsibility, 
we identify two key themes, which resonate with the care literature: responsibility as ethical place-making; and relationships and (re)arrangements between places. Each is elaborated in turn below.

\section{Responsibility as ethical place-making}

Geographers have been at the forefront in recognising that relations are forged through, and implicated in, place-making practices because places are 'the moments through which the global is constituted, invented, coordinated, produced. They are the individual and collective 'agents' in globalisation' (Massey, 2004, p.11) who shape the nature and scope of global inequalities. Moreover, as Iris Young (2003, p.41) suggests:

'Most of us contribute to a greater or lesser degree to the production and reproduction of structural injustice precisely because we follow the accepted and expected rules and conventions of the communities in which we live. Usually we enact standard practices in a habitual way, without explicit reflection on what we are doing, having in the foreground of our consciousness and intention our immediate goals and the particular people we need to interact with to achieve them'.

Thus, it is critical that we recognise the many and varied ways in which this individual and collective agency often operates specifically through the making of place. In the end, it is what people do in place, day-to-day, that makes places what they are, and it is the interactions between people as agents in and across different places that constitutes those places. Any responsible agency needs therefore to be 
understood as a place-making agency. This understanding is a vital and important intervention that geographers have made to the responsibility literature.

Although geographers have theorised the importance of place in defining the contours of responsibility, this is less true of other disciplines. ${ }^{4}$ Thus, for Escobar the marginalisation of place is an important aspect of Eurocentrism, as place offers an important arena for shared identity:

'The marginalisation of place in European social theory of the nineteenth and twentieth centuries has been particularly deleterious to those social formulations for which place-based modes of consciousness and practices have continued to be important... The reassertion of place thus appears as an important arena for rethinking and reworking Eurocentric forms of analysis' (Escobar, cited in Escobar, 2001, p.141).

This reassertion of place by geographers highlights the inherently relational nature of responsibility and urges us 'to do something about it' (Massey, 2004, p.10). The specificity of place in writing about responsibility is important because without finely tuned contextualisations, discussions of responsibility become generalised and fail to anchor in specific political projects. As a result, responsibility can be readily appropriated into an individualised, 'responsibilised' agenda, (including that surrounding responsibilities and UK citizenship, Clark, 2005) rather than one based on carefully tuned responsiveness and attentiveness. Responsibility as ethical placemaking therefore really matters! 
A second body of work on geographies of responsibility focuses on relations and (re)arrangements between places and how a place not only produces responsibilities to that place but also responsibilities to other places. Viewing responsibility as inherently relational opens up a 'configurational politics of responsibility for the nature and effects of that wider geography of relations through which we are made' (Massey, 2006b, p.94).

These responsibilities are not to a distinct or separate 'other' but rather, the 'other' interpellates to produce us. Arturo Escobar's (2001) review of anthropological studies of identity and place precisely draws out the intersubjective elements of relationships in, of and through place. He points out that phenomenological anthropologists, for example, insist on the need for 'greater sensitivity in capturing intersubjective processes of shared experience' (Escobar, 2001, p.150). Escobar is not here talking about going back to an unquestioning bounded sense of place, but rather that place is constructed intersubjectively, not only between people who live in a place, but also between people who live in different places.

Similarly, for Doreen Massey (2004) recognising that the local is not only constituted by the global but is also constitutive of it has significant implications for how we conceive the responsibilities of individuals in particular places. One consequence of this is that local political responsibility cannot be limited to simply acknowledging that a locale like a global city (see Massey, 2007) is constituted through global relations while still defending those places as local and as 'ours'. It must also challenge the local economic and political processes that enable and constitute those global relations. Instead of the 'inwardlookingness' (Massey, 2006a, p.65) that tends 
to come simply from the recognition that many places have contributed people to a place like London, Massey advocates an 'outwardlookingness' (Massey, 2006b, p.92) that comes from the recognition that London has huge effects on the lives of people in a range of other places. She argues that: 'We are responsible to areas beyond the bounds of place not because of what we have done, but because of what we are' (Massey, 2004, p.16). At a minimum, this gestures to a responsibility based not just on historical exploitation, but also, crucially, on contemporary inequalities.

This focus on place as intersubjectively constructed highlights the multiplicity of locations, as well as the variety of interactions between people who are located differently, that go into making places. This has enormous implications for any formulation of responsible agency based on relational geographies. Escobar's (2001, p.161) work takes as its example the place-making practices of activists in the rainforests of the Pacific region of Columbia, and insists that there be a parallel defence of territorial particularity in order for people in some places to resist appropriation by powerful forces of global capital. The difference between places is summarised by the fact that there is ultimately, 'far more purchase in some places than in others on the levers of globalisation' (Massey, 2004, p.12) and this has consequences for responsibility. This is not to see responsibility in a legal sense of payback or guilt but rather to emphasise its political sense so that its agency is shared. As Young argues (2003, p.42):

'if the injustice is a result of structural processes involving many individuals and institutions engaging in normal and accepted activities, the necessary change requires the cooperation of many of those individuals and 
institutions... those who can properly be called victims of structural injustice often share the responsibility to try to change the structures.'

In other words, responsibility for change is not the preserve of the relatively powerful acting on behalf of the relatively powerless, but is a dialogic, intersubjective process.

Moreover, an intersubjective reading also suggests that our responsibility to ourselves and that to others are not clearly demarcatable - the boundaries between outside and inside in relation to place and, by implication, the boundaries between self and other (see Noxolo et al., 2008, for a more detailed treatment of the postcolonial within) are always blurred. 'Inwardlookingness' (Massey 2006a, p. 65) and 'outwardlookingness' (Massey, 2006b, p.92) are no longer clearly distinguishable, as Massey clarifies in relation to London (2004, p.17). She suggests that the relationships between people's responsible agency and the making of place are highly differentiated within the city itself:

'Londoners' are located in radically contrasting and unequal positions in relation to today's globalisation... The political argument should be about how those small and highly differentiated bits of all of us which position us as 'Londoners' give rise to responsibility towards the wider relations on which we depend'. (Massey, 2006b, p. 92)

The corollary of this is that the places that are constituted as outside London are themselves often also profoundly internally differentiated in relation to London, with a wide range of postcolonial intimacies and estrangements to and from the city and its inhabitants. Place-making in terms of relational geographies can therefore be understood as a complex mixture between 'inwardlookingness' and 
'outwardlookingness', a simultaneous co-presence. Henry et al.'s (2002) analysis of globalization in Birmingham, England, gives something of the Janus-like flavour of this thoroughly networked sense of place, in which relationships between individuals/collectivities and place (and, by extension their place-based sense of responsibility) is often orientated as much around relations with other places, as around relations with other people in Birmingham. Though this networked transnationalism is most clearly understood in relation to (particularly the business practices of) relatively recently-migrated ethnic groups, Young's (2003) picture of the banal localised agency of individuals in globalisation (as quoted above) is such that Janus-faced inward/outwardlookingness is an increasingly important part of the lives of almost everyone in large conurbations, and increasingly in rural areas (Hickley 2007), whether or not they are aware of it. It is such complex relations and rearrangements between places that form a second important strand of the geographies of responsibilities literature.

In reviewing the geographical literature on care and responsibility, we have identified some overarching themes in the way that care and responsibility are currently imagined and talked about. In the next section we aim to explore how these concepts and their relationalities may be complicated, and sometimes extended, by adopting a postcolonial analysis. We suggest that their encounter with postcolonialism can perceptively shift the frame - to one in which care and responsibility are understood to be historicised, fractured and contested relations. In adopting such a 'nonnormative' approach to care and responsibility we hope to assist 'the frequently conflict-laden, intense, gritty, and fleshy character of relationships to surface ... rather than remaining submerged by a paradigm which sees them as messy exceptions or 
flaws' (Cooper, 2007, p.257). Below we explore three ways in which a postcolonial reading might open up responsibility and care: through challenging the idea of proximate and distant relations; by rethinking the frame of temporality; and in questioning the centre from which care and responsibility can be talked about. ${ }^{5}$

\section{(Re)Thinking Postcolonial Responsibilities and Care}

First, a key and underlying feature of postcolonial theory is that it interrogates the understandings of distance in socio-spatial relations, asking who is near and who is far (Allen, 2003; 2006)? It questions, what is distance and asks where is the centre from which distance and proximity are measured? Postcolonial responsibility means that we are not talking about 'distant others' but others whose lives and modes of living are still proximate (and have been for some time) and influenced by (neo)colonialism in its variegated forms. This complex claim of belonging to, and proximity with, people and places that are often seen as separated through inexorable difference is summarised by George Lamming's claim that: 'The pleasure and paradox of my own exile is that I belong wherever I am' (Lamming, 1960, p.50). This complex and painful interdependence, this mutuality, poses challenges for thinking about both care and responsibility. Through a postcolonial lens we would argue that the notion of distance gets altered as all of us are already implicated in each other's 'presents' in complicated ways. Lines of caring and responsibility are therefore unclear and not wholly pre-decided but do have traces from the past and implications for the future. In sum, postcolonial responsibility and care fold up, and reopen, space in complicated ways (Madge et al., this issue). 
At the same time, as postcolonial theorists have argued, there are still spaces in many parts of the world that are not entirely determined through their relations with each other (Mufti, 2005), so that while postcoloniality requires us to recognise the mutual constitution of different geographical places and the importance of each for the other's formations, it also forces us to acknowledge that places are not always entirely constituted through this relation. Postcolonial theory therefore forces us to acknowledge abruptness and separation as well as connections and flows. It suggests a complex spatial equation whereby places can be a part of, whilst still being apart from, other places. Being responsible then involves taking account of, but also being accountable to, both the connections and the disconnections, between these different spaces and places and their distinctive world picturing (cf Noxolo et al., 2008). This has implications for thinking through care and responsibility. For example, lines of responsibility are not always clear because we have to always ask ourselves, responsibility in what spaces, places, times and for which people? What are the limits to responsibility and how are these worked through in different spatial arrangements? When does acting responsibly mean refusing to be responsible? It also suggests the limits to care: who benefits from delivering care? Is care necessarily good for the carer/cared? When does caring actually become an irresponsible act?

A second major challenge to thinking about responsibility and care through the postcolonial frame concerns temporality. Instead of seeing responsibility as coming out of relationality over spatial distance rather than temporal distance (see Massey, 2004, p.10), or even attempting to see time and space as resolved in space-time, postcolonial literature engages time as a challenge to the notion of distance (and the pervasive, but historically anomalous figure of the 'stranger' that it brings with it, see 
Massey, 2004, p.10; and Corbridge, 1993). As Bhabha (1995) has argued, the historical and contemporary mutuality of relationships between the formerly colonised and the formerly colonising has often been denied. Thus Western discourses around the global South, including development discourses, produce Africa, Asia, Latin America, the Caribbean in terms of absences, rather than presences, in terms of that which the North has that they do not. For Sousa (2003, p.238-239) five 'monocultures' have helped produce these 'absences' within colonial and post-independence development discourses: monocultures of knowledge, linear time, classification, the universal/global, and the criteria of capitalist productivity and efficiency. These monocultures shape the imaginaries of both the global North and the South, so that some people and places are treated as temporal anachronisms (Hindess, 2007). This denial of coevalness (related to the discourse of linear time) has meant that the shared presence and shared relationship of the North with other places has not been acknowledged, and it is this temporality that postcolonial theory critiques most consistently (see Slater, 2004).

However, this insistence that places cannot be plotted at different points on a unilinear map of historical progress does not necessarily mean that temporality should be seen as entirely shared. Homi Bhabha criticises Foucault's spatial imaginary of the West (Euro-America) alone as too restricted, necessitating 'homogenising spatial metaphors that do not allow for the different disjunctive temporalities of other cultural articulations' (Bhabha, 1995, p. 83, our emphasis). As Wilson Harris has noted in relation to Caribbean history, it is often impossible to see the history of places that have been characterised by repeated invasions and brutal forced migrations in terms of having a linear history that can be placed alongside a Western linear history, even 
in terms of coevalness: 'how can one begin to reconcile the broken parts of such an enormous heritage, especially when those broken parts appear very often like a grotesque series of adventures...' (Harris, 1967, p.31). Temporality therefore becomes in itself a source of difference.

This understanding of temporality as neither continuous nor necessarily coeval but fractured and selectively incorporated means that calls to take account of historical relations in order to shape the nature and direction of responsibility and care become far from simple. Thus we would, for instance, agree with Tronto (2003) that narratives of speed and of contingency privilege future orientations and instantiations while there is much less that forces us to take account of the past. She argues that while forgetting past injustices may be used as a way of invoking contemporary agency, the structures and limitations of the past in shaping that agency may too easily be forgotten. It leaves no room for remedying past injustices or for moving towards a responsible accountability. According to Tronto (2003, p.133) then:

'The only solution to systematic ignorance is to try painstakingly to construct or reconstruct knowledge. The solution to these problems, then, is not to wish for a brave new world, to recommend that we should consider only the future. Instead, we need to return to the painful, ugly and yet perhaps redeemable excesses and injustices of the past, perpetrated by women and men, on men and women, throughout the world. Only if we are willing to give the past its due will we have any firm ground to stand upon and pursue hope for the future.' 
We therefore concur that remembering the past is important, because forgetting or 'disremembering' the past may lead to forms of disintegration and denial that are damaging to responsible and 'care-full' agency. However, remembering the past, and even apologising for it (see Gatens and Lloyd, 1999), may be cleansing but is not in itself a simple remedy for past injustices. Spectral imaginings of the hauntedness of the present in which place is constantly made and re-made show us that it is not always possible to remedy the past. Perhaps more generative is the imagination of other times that might (or might not) be 'emergent' (Sousa, 2003, p.242) from our immanent global relationality. For example, Paul Gilroy (1993, p.68) talks of enslaved/colonised people's repeated re-imagining of the 'jubilee' moment, a time outside of time, in which those who are disavowed and displaced will find a place. The effect of this spectral 'other time' is to constantly remind us that all existing social formations, including place, are fully contingent and uninevitable, which is the starting condition for a 'politics of the possible' (Sangari, 1990).

Finally, postcolonial thinking also challenges the centre from which care and responsibility can be talked about. Postcolonial theory is crucially concerned with the ability to write/speak back (Ashcroft et al., 1989), because its object is not only the decentring of the West but crucially a re-balancing of the West with the rest of the world (Hall, 1992). It deconstructs the enlightenment subjectivities that defined the colonial and 'othered' rest of the world in relation to it, but crucially it also seeks to re-constitute subject positions from which people around the world can find voice to speak about themselves. This decentering can also be usefully extended to care and responsibility: What does care look like for different people from different centers? Drawing on humanism, the contours of care are often presumed and defined by ethical 
values which masquerade as universal, a universality that is deeply challenged by postcolonial contributions. Similarly, we may well ask how responsibilities might change with insistence of 'voicing' those who have been left out of the script for far too long? In a telling example, Koschade and Peters (2006) discuss how Algonquin communities in Canada conceive of space and responsibility in deeply ecological, rather than narrowly juridical, terms. They argue that Algonquin concepts of knowledge, land and jurisdiction are incompatible with existing Euro-Canadian divisions of legal responsibility and ecological knowledge, but at the same time such incompatibilities can offer the means to challenge the current structure of Aboriginal and Canadian relations and can seek to forge dialogue that inserts a multiplicity of concepts and ways of understanding onto the institutional agenda. This example suggests that postcolonial responsibility must involve willingness and ability to respond to what the postcolonial public might have to say about how different presents are co-produced. Here we are not arguing for some 'authentic Southern voice' but rather that there is a shared immanent relationship that can form the basis for decentring the nature and direction of responsibility. This may involve a 'splintering' of familiar ways of understanding self and other relationships, by unsettling the coherence and integrity ascribed to both centre and periphery.

Thus shifting the centre can challenge conceptualisations of what responsibility might actually mean and alert us to the range of responses that could be evoked in the 'reaching out' that marks responsibility. For one, the ability to speak and to hear may both be muted for complex reasons. For instance, pernicious bio politics removes some global citizens from beyond the care of the state (Sylvester, 2006), putting these citizens' voices out of circulation, enclosing their bodies, and foreclosing the forms of 
interconnectedness in which they are embedded (Vasudevan et al. forthcoming). On the other hand, responsibilities that are enacted may well be refuted by the 'other'. Taking responsibility may be seen as an act of complicity with colonialism - after all, colonialism was itself justified through tales of universalism and in defence of humanism (Lester, 2002). To posit responsibility in a finite future is to (re)colonise responsibility. For instance, as Mezzadra and Rahola (2006, p.5) argue, this form of responsibility may simply deprive:

'the insurgent colonised subject, the rebellious subaltern, of all possible forms of agency or of any possibility of directly intervening in history; selfabsolution, to the extent that it eliminates from history all direct responsibility that is not identified with the colonial West and, so too, any revolutionary act that does not belong to the West, not only hands over all responsibility from but also - and above all - shifts action from the colonised subject to the eternal (neo-)colonial Subject.'

We therefore suggest that responsibility and care are always left open to the multiple meanings that they may take in various places. To do so refutes an approach to responsibility and care that assumes an asymmetry in focusing on 'the fragility of the other' and the 'radical generosity of altruistic existence' (Beasley and Bacchi, 2007, p. 285). Instead it urges an approach to responsibility and care which focuses on interdependence and coexistence and makes apparent the potential connections between responsibility, care and power, at a variety of scales (Beasley and Bacchi, 2007, p. 286).

\section{Conclusions and introductions}


In this article we have argued that both responsibility and care have much to offer in thinking about relationalities in a postcolonial world. Geographers' efforts to locate these terms within narratives of interdependency - spatially and temporally - has done much to challenge dominant tendencies within contemporary political systems to posit these inherently relational words within the context of individuation and autonomy. The papers in this special issue take this project further by routing these terms through the critical terrain of postcolonialism where interdependency is not cosy but is seen as contested, complicated and productively unsettling. They show that routing care and responsibility through postcolonial geographies incites us towards a more embodied pragmatic responsiveness, one that makes a 'care-full' recognition of postcolonial interaction.

These papers explore this postcolonial interaction in all its complexity. Marcus Power's paper 'The Commonwealth, 'development' and post-colonial responsibility' focuses on the Commonwealth's contemporary sense of 'responsibility' for shaping African 'development' through 'partnerships' and by promoting 'good governance'. Power usefully examines the continuing post-colonial interaction between Britain and its Commonwealth, specifically using the case of Mozambique, to highlight continuing British neo-colonial paternalism based on a sense of trusteeship and an unproblematised vision of African development. Parvati Raghuram also explores this postcolonial interaction in her paper 'Caring about 'brain drain' migration in a postcolonial world'. Here Raghuram argues that current discussions of health worker mobility from the South to the North, which centre around brain drain, are somewhat limited because they fail to see the layers of interaction that have shaped what we see as health or what becomes constituted as health work. She argues for the need to 
adopt a spatial lens that recognises the histories of mobility that shaped health work globally but also the health care sector in the UK specifically. Clare Madge et als' paper 'Engaged pedagogy and responsibility: a postcolonial analysis of international students' concentrates on the increasing internationalisation of the UK higher education system, illustrating how such contemporary global connections are also a reflection of historical, postcolonial interaction. They scrutinize the implications of these interactions for academic responsibilities in relation to international students within everyday academic practices.

In addition to exploring postcolonial interaction, in this introductory paper we have also argued that postcolonial perspectives on responsibility urge us to become attuned to both the ways in which temporalities of the past seep through to form the present and also to remain vigilant to those historical relations which remain hidden, unrecognisable or have mutated. This means that the directions and shape of responsibility and care are not wholly traceable, leaving room for the surprising, the unanticipated and therefore for a responsibility where who is being responsible to whom becomes less clear-cut, more labile. At its heart, postcolonial analysis therefore raises questions surrounding the responsibilities that people in different parts of the world bear to each other and their ability and desire to care for each other. It suggests that these issues have to be worked out in each instance but in working it out this inherent ambivalence and ambiguity of space and place can unsettle responsibility and care. It is this unsettling that we have explored in our article. As such, our paper contributes towards moves being made elsewhere (see, for example, Cupples et al., 2007) to destabilize and disrupt the linear temporalities and spatial fixities of much development/geographical thought and practice. 
This unsettling is also followed through in several papers in the special issue. Gillian Rose's paper 'Who cares for which dead and how?' draws on Mbembe's formulation of 'necropolitics' to interrogate media coverage of the London bombings in July 2005. She focuses, in particular, on the gendering and racialisation of bodies in photographs, arguing that this complex visual economy worked to place the reader into particular relationships of caring (or otherwise) in relation to the dead. Patricia Noxolo turns her attention to academic writing in her paper "“My paper, my paper": reflections on the embodied production of postcolonial geographical responsibility in academic writing'. Noxolo uncovers the way in which the body 'speaks' in academic writing, arguing that it is within the multiple materialities of the body that a responsible politics of postcolonial writing can most fruitfully be located.

Finally, several papers in this special issue also show how responsibility and care might appear, not from an imagined centre, but from other different positions, including those who are distant and those who help to constitute the centre through their presence. Jenny Pickerill's paper 'Finding Common Ground' explores the ways in which responsibilities towards the environment are negotiated through interactions between Indigenous and non-Indigenous activists in environmental campaigns in Australia, recognising the need for dialogue across different views of scale, as well as between different claims and concepts of ownership and control. Claire Newstead's paper 'Pedagogy, post-coloniality and care-full encounters in the classroom' considers what it means to take up the political post-colonial commitment to simultaneously critique and destabilise pedagogic practice. Through the use of fiction in an undergraduate course on the post-colonial Caribbean, Newstead attempts to encourage 
more open-ended and responsive encounters to Caribbean people and places, to encourage students to develop fresh ways of working with inequality and difference. These papers thus call for contingent negotiated readings of responsibility and care that take on board the complexities of local configurations of power and the specificities of geographical and historical context.

What all the papers in this special issue suggest is that by reading postcolonialism not as the sanitised 'after-colonialism' but as anti-colonialism, an unanticipated set of emotions and painful imperatives flow through into both responsibility and care. Anticolonialism charges responsibility and care with emotions such as anger, anticipation and hope that make responsibility not a burden but forward-looking: it contains 'alternative visions, alternative understandings of how the world could be better' (Gilmartin and Berg, 2007, p.120). In recognising the power of enlivening pain it suggests vivaciousness and energy for change which occurs both through, and despite of, hardship, sacrifice and loss that other forms of responsibility do not quite muster. And these productive emotions can form the basis for generating long-term embodied and pragmatic responsiveness.

In this special issue we are also moved towards thinking about postcoloniality with responsibility and care. This is important because postcolonial theory enters the western academy as a demand for inclusion of those who have been marginalised and dispossessed, but crucially it is a demand for inclusion, not by becoming the same, but for inclusion of that difference. Postcolonial theory is therefore not just 'the next big thing' - it makes a demand for change. Ultimately, for geography as a discipline, perhaps the most important and timely contribution we would like to make is to 
encourage that postcolonial theory itself be treated responsibly and with care so that its promise of radical change is carried through.

\section{References}

Allen, J., 2003. Lost Geographies of Power. Blackwell, Oxford.

_., 2006. Claiming connections: a distant world of sweatshops. In C. Barnett, J. Robinson and G. Rose (Eds), A Demanding World. Open University Press, Milton Keynes. pp. 7-55

Andreasson, S., 2005. Orientalism and African Development Studies: the 'reductive repetition' motif in theories of African underdevelopment. Third World Quarterly 26 (6), 971-986.

Armstrong, A., 2006. Ethical issues in water use and sustainability. Area 38 (1), 9-15. Ashcroft, B., G. Griffiths, and H. Tiffin. 1989. The Empire Writes Back: Theory and Practice in Postcolonial Literature. London, Routledge.

Baldwin, A. 2004. An ethics of connection: social-nature in Canada's boreal forest. Ethics, Place and Environment 7 (3), 185-194.

Barnett, C. 2005. Ways of relating: hospitality and the acknowledgement of otherness. Progress in Human Geography 29 (1), 5-21.

Barnett, C., and C. Land. 2007. Geographies of generosity: beyond the 'moral turn'. Geoforum 38, 1065-1075.

Beasley, C., and Bacchi, C., 2007. Envisaging a new politics for an ethical future: Beyond trust, care and generosity towards an ethic of 'social flesh'. Feminist Theory 8 (3), 279-298.

Beaumont, J., M. Loopmans, and J. Uitermark. 2005. Politicization of research and the relevance of geography: some experiences and reflections for an ongoing debate. Area 37 (2), 118-126. 
Bhabha, H., 1995. Translator translated: conversation with Homi Bhabha Artforum 33 (7), 80-84.

Biccum, A., 2005. Development and the 'new' imperialism: a reinvention of colonial discourse in DFID promotional literature. Third World Quarterly 26 (6), 1005 1020.

Bondi, L., 2003. A situated practice for (re)situating selves: trainee counsellors and the promise of counselling. Environment and Planning A 35, 853-870.

Bosco, F. J., 2007. Hungry children and networks of aid in Argentina: thinking about geographies of responsibility and care. Children's Geographies 5, 55-76.

Brock, G., 2005. Does obligation diminish with distance? Ethics, Place and Environment 8 (1), 3-20.

Brown, M., 2003. Hospice and the spatial paradoxes of terminal care. Environment and Planning A 35 (5), 833-851.

Clarke, J., 2005. New Labour's citizens: activated, empowered, responsibilized, abandoned? Critical Social Policy 25 (4), 447-463.

Clarke, N., C. Barnett, P. Cloke, and A. Malpass. 2007. Globalising the consumer: Ethical consumerism and new repertoires of public action. Political Geography $26(3), 231-249$.

Cloke, P., 2002. Deliver us from evil? Prospects for living ethically and acting politically in human geography. Progress in Human Geography 26, 587-604.

Conradson, D., 2003. Geographies of care. Spaces, practices, experiences. Social and Cultural Geography 4 (4), 455-547.

Cooper, D., 2007. 'Well, you go there to get off': Visiting feminist care ethics through a women's bathhouse. Feminist Theory 8 (3), 243-262. 
Corbridge, S., 1993. Marxisms, modernities, and moralities: development praxis and the claims of distant strangers. Environment and Planning D: Society and Space $11(4), 449-472$.

— 1998. Development ethics: distance, difference, plausibility. Ethics, Place and Environment 1, 35-54.

Cupples, J., Glynn, K and Larios, I. 2007. Hybrid Cultures of Postdevelopment: The Struggle for Popular Hegemony in Rural Nicaragua. Annals of the Association of American Geographers, 97 (4), 786 - 801.

Davies, G., 2006. Patterning the geographies of organ transplantation: corporeality, generosity and justice. Transactions of the Institute of British Geographers 31 (3), 257-271.

Environment and Planning A. 2003. 35 (5).

Esping-Andersen, G., 1999. Social Foundations of Post Industrial Economies. Oxford University Press, Oxford.

Escobar, A., 2001. Culture sits in places: reflections on globalism and subaltern strategies of localization. Political Geography 20, 139-174.

Fannin, M., 2003. Domesticating birth in the hospital: 'family-centered' birth and the emergence of 'homelike' birthing rooms. Antipode 35, 513-35.

Folbre, N., 2006. Measuring care: gender, empowerment and the care economy. Journal of Human Development 7 (2), 183-199.

Gatens, M., and G. Lloyd. 1999. Collective Imaginings: Spinoza, Past and Present. Routledge, London.

Geoforum. 2007. 38(6) Geographies of Generosity.

Geografisker Annaler B. 2004. 86. 
Gibson, C., 2006. Decolonizing the production of geographical knowledges?

Reflections on research with indigenous musicians. Geografiska Annaler, Series B: Human Geography 88 (3), 277-284.

Gilmartin, M., and L. Berg. 2007. Locating postcolonialism. Area 39 (1), 120-124.

Gilroy, P., 1993. One nation under a groove. In Small Acts: Thoughts on the Politics of Black Cultures, ed. P. Gilroy, 19-48. Serpent's Tail, London.

Hall, S., 1992. The West and the rest: discourse and power. In: S. Hall and B. Gieben (Eds) Formations of Modernity, 275-332. Polity Press, Cambridge.

Harris, W., 1967. Tradition, the Writer and Society: Critical Essays. New Beacon, London.

Hay, I., and P. Foley. 1998. Ethics, geography and responsible citizenship. Journal of Geography in Higher Education 22, 169-309.

Henry, N., C. McEwan, and J. S. Pollard. 2002. Globalization from below: Birmingham - postcolonial workshop of the world? Area 34 (2), 117-127.

Hickley, M. 2007. Number of immigrants in rural England trebles in three years. Daily Mail, 17th July.

Hillman, M. 2004. The importance of environmental justice in stream rehabilitation. Ethics, Place and Environment 7 (1-2), 19-43.

Hindess, B. 2007. The past is another culture. International Political Sociology, 1 (4) $325-338$

Hobson, K. 2006. Environmental responsibility and the possibilities of pragmatistorientated research. Social and Cultural Geography 7 (2), 283-298.

Hochschild, A. 2000. Global care chains and emotional surplus value. In On the Edge. Living with Global Capitalism, eds. W. Hutton and A. Giddens, 130-146 Jonathan Cape, London. 
Hughes, B., L. McKie, D. Hopkins, and N. Watson. 2005. Love's labours lost? Feminism, the Disabled People's Movement and an ethic of care. Sociology $39,259-75$.

Ilcan, S., M. Oliver, and D. O’Connor. 2007. Spaces of governance: gender and public sector restructuring in Canada. Gender, Place and Culture: a Journal of Feminist Geography 14 (10), 71-92.

Jazeel, T., 2007. Awkward Geographies: spatializing academic responsibility, encountering Sri Lanka. Singapore Journal of Tropical Geography, 28(3), 287299

Johnsen, S., P. Cloke, and J. May. 2005. Day centres for homeless people: spaces of care or fear? Social and Cultural Geography 66, 787-812.

Kapoor, I., 2004. Hyper-self-reflexive development? Spivak on representing the third world 'other'. Third World Quarterly 25 (4), 627-647.

Kofman, E., and Raghuram, P., 2007. The Implications of Migration for Gender and Care Regimes in the South, Paper presented at UNRISD workshop 'Social Policy and Migration' 22-23 November, Stockholm.

Kofman, E. and Raghuram, P., 2006. Gender and global labour migrations: incorporating skilled workers. Antipode 38 (2), 282-303

Koschade, B., and E. Peters. 2006. Algonquin notions of jurisdiction: Inserting indigenous voices into legal spaces. Geografiska Annaler Series B-Human Geography 88B (3), 299-310.

Lamming, G., 1960. The Pleasures of Exile. Ann Arbor, Michigan.

Lawson, V., 2007. Geographies of care and responsibility. Annals of the Association of American Geographers 97 (1), 1-11. 
Lester, A., 2002. Obtaining the "Due Observance of Justice": The geographies of colonial humanitarianism. Environment and Planning D: Society and Space 20 (3), $277-293$.

Madge, C. Raghuram, P. and Noxolo, P. this issue. Engaged pedagogy and responsibility: A postcolonial analysis of international students. Geoforum Massey, D., 2004. Geographies of responsibility. Geografiska Annaler 86, 5-18.

- 2006a. London inside-out. Soundings: a journal of politics and culture 32, $62-71$.

. 2006b. Space, time and political responsibility in the midst of global inequality. Erdkunde 60 (2), 89-95.

—. 2007. World City., Polity Press, London.

McDowell, L. 2004. Work, workfare, work/life balance and an ethic of care. Progress in Human Geography 282 (145-164).

McKie, L., S. Gregory, and S. Bowlby. 2002. Shadow Times: The Temporal and Spatial Frameworks and Experiences of Caring and Working. Sociology 36 (4), 897-924.

Mezzadra, S., and F. Rahola. 2006. The postcolonial condition: A few notes on the quality of historical time in the global present. Postcolonial Text II, 1

Milligan, C. 2003. Location or dis-location? Towards a conceptualization of people and place in the care-giving experience. Social and Cultural Geography 44, 455-470.

Mufti, A., 2005. Global Comparativism. Critical Inquiry 31, 472-489.

Noxolo, P., P. Raghuram, and C. Madge. 2008. 'Geography is pregnant' and 'Geography's milk is flowing': metaphors for a postcolonial discipline? Environment and Planning D: Society and Space 26 (1), 146-168. 
Parr, H., 2003. Medical geography: care and caring. Progress in Human Geography 27 (2), 212-221.

Parreñas. R., 2000. Migrant Filipina Domestic Workers and the International Division of Reproductive Labor. Gender \& Society 14(4), 560-80.

Parreñas. R., 2001. Servants of Globalization: Women, Migration, and Domestic Work, Stanford University Press, Stanford, CA.

Patai, D. 1991. US academics and Third World Women: Is ethical research possible? In: G. S. B. Gluck and D. Patai (Eds.) Women's Words: The Feminist Practice of Oral History, 137-154 Routledge, London.

Popke, J., 2006. Geography and ethics: everyday mediations through care and consumption. Progress in Human Geography 30, 504-512.

-2007. Geography and ethics: Spaces of cosmopolitan responsibility. Progress in Human Geography 31, 509-518.

Popke, J. E., 2003. Poststructuralist ethics: subjectivity, responsibility and the space of community. Progress in Human Geography 27 (3), 289-316.

Raghuram, P., and C. Madge. 2006. Towards a method for postcolonial development geography: possibilities and challenges. Singapore Journal of Tropical Geography 27 (3), 270-288.

Raghuram, P. and Noxolo, P and Madge, C. Envisaging care-full postcolonial responsibility. To be submitted to Transactions of the Institute of British Geographers.

Razavi, S., 2007. The Political and Social Economy of Care in a Development Context. Conceptual issues, research questions and policy options. Gender and Development Paper no. 3, UNRISD, Geneva. 
Richardson, P., 2004. Agricultural ethics, neurotic natures and emotional encounters: an application of actor-network theory. Ethics, Place and Environment 7 (3), 195-201.

Sangari, K., 1990. The politics of the possible. In The Nature and Context of Minority Discourse, eds. A. JanMohamed and D. Lloyd, 216-245, Oxford University Press, Oxford.

Sevenhuijsen, S., 2003. The place of care: the relevance of the feminist ethics of care for social policy. Feminist Theory 4 (2), 179-197.

Sharp, J., and J. Briggs. 2006. Postcolonialism and development: new dialogues? The Geographical Journal 172 (1), 6-9.

Silk, J., 2004. Caring at a distance: gift theory, aid chains and social movements. Social and Cultural Geography 5 (2), 229-251.

Slater., D., 2004. Geopolitics and the Post-colonial: Rethinking North-South Relations. Oxford, Blackwell.

Smith, D., 2002. Responsibility to distant others. In: V. Desai and R. B. Potter (Eds), The Companion to Development Studies 131-135, Arnold, London.

Smith, S., 2005. States, markets and an ethic of care. Political Geography 24, 1-20. Social and Cultural Geography. 2003. 4 (4).

-.2004. 5 (2).

Sousa Santos, B., 2003. The World Social Forum: Toward a Counter-hegemonic globalisation. In J. Sen, A. Anand, A. Escobar and P. Waterman (Eds) 2004 World Social Forum : Challenging Empires 349-358. New Delhi, Viveka. Sparke, M., 2007a. Geopolitical Fears, Geoeconomic Hopes, and the Responsibilities of Geography. Annals of the Association of American Geographers 97(2), $338-349$. 
Sparke, M., 2007b. Acknowledging responsibility For space, Progress in Human Geography 31, 395-403.

Spivak, G., 2007. Other Asias. Blackwells, Oxford.

Staeheli, L., and M. Brown. 2003. Where has welfare gone? Introductory remarks on the geographies of care and welfare. Environment and Planning A 35 (5), 771777.

Sylvester, C., 2006. Bare life as a development/postcolonial problematic. The Geographical Journal 172 (1), 66-77.

Tronto, J., 2003. Time's place. Feminist Theory 4 (2), 119-138.

Ungerson, C., 1999. Personal assistants and disabled people: an examination of a hybrid form of work and care. Work, Employment and Society 13 (4), 583600.

Ungerson, C., and S. Yeandle. 2007. Commodified Care in Developed Welfare States, Palgrave MacMillan, Basingstoke.

Vasudevan, A., C. McFarlane, and A. Jeffrey (forthcoming) Spaces of Enclosure. Geoforum.

Yeates, N., 2004. Global care chains: critical reflections and lines of enquiry. International Feminist Journal of Politics 6 (3), 369-391.

Young, I. M., 2003. From guilt to solidarity: sweatshops and political responsibility. Dissent (Spring), 39-44. 
Notes

${ }^{1}$ We privilege place in our discussion as this is one of the key routes through which the responsibilities literature links responsibility and agency. But we see placemaking as an intersubjective process (cf Escobar, 2001). Moreover, although the literature privileges urban places, our argument extends to all places- urban, suburban, market towns, rural areas- all of which are co-produced through a 'distant localness'.

${ }^{2}$ While all of the above literature locates care as a relationship between individuals, Susan Smith (2005) significantly extends this argument by showing that affect and responsibility can be applied to markets as much as to individuals. Through an example of how people care about housing, she lays out some ways in which people invest emotionally in markets. Caring about institutional practices, she suggests, can contribute much to understandings of participation in voluntary organisations and trade unions.

${ }^{3}$ Other discussions of responsibility in geography have revolved around responsible research praxis, political commitment and social justice, often articulated through the lens of responsible citizenship (Beaumont et al., 2005; Cloke, 2002; Davies, 2006; Gibson, 2006; Hay and Foley, 1998) but we do not focus on these here.

${ }^{4}$ But in literature see Spivak (2007). And for our more serious engagement with Spivak's writing on the subject see Raghuram et al. (forthcoming). 
${ }^{5}$ Delinking time from space is itself an artificial process that occludes questions such as what kinds of spatial arrangements led to certain pasts? And how were time and space co-produced in these moments? What lines from the past came forward to shape present temporalities and spatialities? 